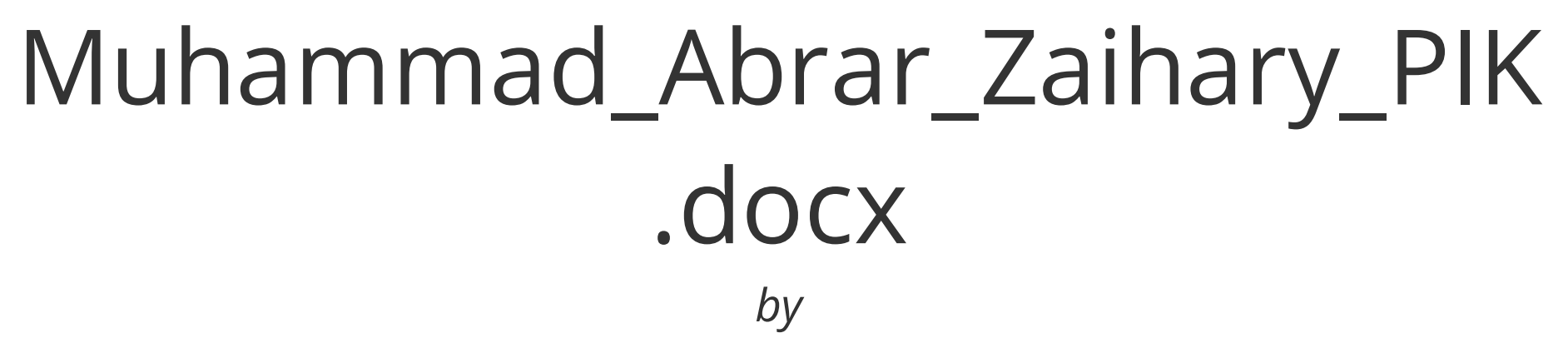

Submission date: 02-Jan-2022 08:36PM (UTC+0700)

Submission ID: 1736867981

File name: Muhammad_Abrar_Zaihary_PIK.docx (46.62K)

Word count: 3161

Character count: 21556 


\title{
PERANAN SISTEM PENGAMBILAN KEPUTUSAN (dss) \\ DALAM SIM
}

\section{MUHAMMAD ABRAR ZAIHARY (0702212220)}

Email: muhammadabrarzaihary@gmail.com

SAINS DAN TEKNOLOGI

SISTEM INFORMASI 6

2021

\begin{abstract}
Abstrak
Di era yang semakin modern pada saat ini dan semakin berkembangnya teknologi kita sebagai orang-orang yang juga pengguna teknologi tersebut terus berkembang dan terus mencetuskan ataupun mengeluarkan cara-cara memanfaatkan teknologi tersebut dan membaginya menjadi beberapa sistem yang sistem tersebut berguna untuk mempermudah penggunanya dalam menjalankan sebuah pekerjaan ataupun program yang lebih efisien dalam membantu mencari informasi, mengambil keputusan, serta menganalisis situasi pasar yang sedang terjadi pada saat ini. Adapun beberapa sistem tersebut diantarnya: sistem informasi manajemen, sistem informasi manajemen adalah sebuah sistem yang banyak digunakan dalam suatu perusahaan. Sistem informasi manajemen berguna untuk memperoleh suatu keputusan yang dapat diperoleh oleh manajer dan juga dapat memberikan suatu informasi yang telah di analisis untuk di berikan kepada seorang manajer. Sistem Informasi Manajemen biasanya di gunakan untuk para manajer ataupun para pemimpin perusahaan digunakan untuk mencari informasi, menganalisis, menentukan sebuah keputusan, dan sebagainya.
\end{abstract}




\section{Pendahuluan}

Seperti yang kita ketahui bahwasanya setiap hari, bulan dan maupun tahun ke tahun bahwasannya semakin berkembangnya manusia ataupun semakin menambahnya populasi penduduk bumi di samping itu pula semakin berkembangnya teknologi yang dapat membantu kita dalam mempermudah suatu pekerjaan yang tidak dapat kita lakukan dengan cepat dan lebih efisien. Dampak dari perkembangan teknologi itulah kita sengaja pengguna teknologi juga dapat menghasilkan sistem pengoperasian dalam pekerjaan kita, dan sistem-sistem tersebut juga terdapat di dalam perusahaan maupun dalam suatu lembaga, ataupun yayasan untuk mempermudah mengorganisir suatu perusahaan, lembaga, dan yayasan tersebut.

Sistem-sistem tersebut juga terdapat dalam dunia pemasaran, yang dimana sistem tersebut dapat mempermudah kinerja yang lebih efisien dalam menggunakannya, dengan menggunakan sistem tersebut kita dapat memasarkan suatu barang dengan lebih terorganisir, sistem tersebut dapat ataupun sering kita sebut dengan ecommers. E-commers atau juga kita sebut dengan perdagangan elektronik adalah suatu sistem yang di dalamnya terdapat teknologi, aplikasi sebuah bisnis yang dapat menghubungkan konsumen dengan perusahaan ataupun seseorang dalam Memperdagangkan suatu barang melalui sebuah website atau pun yang biasanya sering kita sebut dengan world web wide (www) yang di mana dengan menggunakan sistem tersebut dia lebih mudah untuk menyortir, menganalisis, dan memperjual belikan suatu barang yang akan di perjual belikan. Dengan berkembangnya juga sistem perdagangan elektronik banyak munculnya orang-orang yang memanfaatkan sistem tersebut dengan mencari peluang dan mendirikan perusahaan-perusahaan seperti GO-JEK, Grab, JNT, JNE, Sicepat, Tokopedia, Shopee, dan sebagainya yang dapat memberikan suatu jasa dalam menyortir pengiriman dan pengantaran melalui perusahaan ataupun seseorang yang memperdagangkan barangnya kepada konsumen. Perusahaan-perusahaan tersebut menggunakan sistem yang di mana dapat memberikan informasi yang sangat cepat dan dapat sistem yang dapat menganalisis suatu pembelian produk ataupun jasa vang diinginkan oleh konsumen tersebut, untuk memberikan suatu pelayanan yang dapat 
memuaskan konsumen tersebut untuk berlangganan dalam pelayanan perusahaanperusahaan tersebut. Dengan adanya perusahaan tersebut telah menjadi bukti bahwasannya kita sebagai manusia juga mengikuti dan berkontribusi dalam perkembangan teknologi. Walaupun sebagian orang masih ada yang belum memanfaatkannya di karena kan terlalu keterbelakangan sebuah suatu desa dalam perkembangan memakai sebuah teknologi, oleh karenanya kita harus juga membantu atau menyumbangkan ilmu kita kepada mereka untuk dapat memajukan masyarakat kita.

\section{Kajian Teori}

\section{Makna Sistem}

Sistem adalah sebuah suatu kesatuan yang dapat mengorganisir suatu pekerjaan dengan lebih terstruktur. Sistem juga dapat di pengaruhi oleh penggunanya, di karena kan sebuah sistem dapat terus berkembang dengan di liputi oleh pengguna sekeliling nya. Sistem juga sering di gunakan dalam bidang ilmu pengetahuan, maupun dalam teknologi ataupun dalam suatu organisasi, lembaga, dan yayasan yang dapat di gunakan untuk mengatur susunan kegiatan yang akan dilakukan oleh organisasi tersebut. Sistem juga banyak memiliki makna di dalamnya yang telah diteliti oleh para pakar-pakar ilmuan dalam berbagai jenis bahasa yang telah di tetapkan.

Sistem menurut bahasa Yunani adalah suatu elemen yang saling berhubungan dalam memberikan informasi, materi untuk mencapai sebuah tujuan yang telah di tetapkan. Dalam beberapa kamus pengertian sistem adalah suatu komponen satu set benda yang dapat saling terhubung dan teratur yang saling bekerja sama dalam mencapai sebuah tujuan tertentu. Sistem juga dapat diartikan sebuah organ komputer yang saling berhubungan untuk dapat menjalan suatu komputer tersebut. Sistem juga memiliki beberapa struktur antara lain: komponen sistem, batasan sistem, lingkungan luar sistem, dan penghubung sistem.

Komponen sistem adalah kumpulan dari beberapa komponen yang saling berhubungan, maupun dari sistem itu sendiri ataupun dari sub sistem.

Batasan sistem adalah suatu batasan yang membatasi antara suatu sistem dengan sistem yang lain dan biasanya suatu sistem yang di batasi disebut dengan satu kesatuan. Lingkungan luar sistem adalah yang melebih dari batasan sistem yang dapat menguntungkan dengan memperoleh dan 
tidak menguntungkan agar bisa di kendalikan supaya tidak merusak tatanan sistem tersebut.

Penghubung sistem adalah suatu penghubung antara sub sistem dengan yang lainnya dan dapat mengalirkan data kepada sub sistem lainnya. Dengan adanya struktur sistem ini kita tahu bahwasannya bagaimana kita menjalankan suatu sistem dan mengembangkannya.

\section{Makna Informasi}

Informasi secara etimologi, yang berasal dari bahasa Perancis yang artinya, ide, ataupun secara garis besarnya adalah suatu kumpulan ide yang digunakan dalam berkomunikasi. Pengertian informasi adalah suatu kumpulan data fakta yang telah di proses untuk mudah dipahami oleh orang yang menerima informasi tersebut dan dapat menguntungkannya. Berbeda dengan data yang merupakan suatu mentahan yang belum di proses dan yang masih sulit dipahami oleh yang menerimanya. Dan beberapa para ahli seperti George H. Bodnar yang mengatakan "informasi adalah sebuah data yang diolah sehingga dapat dijadikan dasar mengambil keputusan yang tepat". Dan juga menurut Anton M. Melino yang mengatakan "informasi merupakan data yang telah di proses untuk tujuan tersebut". Informasi juga dapat ditemukan di berbagai media cetak seperti majalah, dan koran, serta juga dapat diakses melalui media online yang terdapat pada website tertentu seperti Google yang terdapat blogblog tertentu yang berisi banyak informasi, Facebook, Instagram, Twitter, dan sebagainya. Informasi juga terbagi menjadi ${ }_{7}$ beberapa jenis yaitu, secara faktual, subjektif, dan objektif. Informasi secara fakta atau faktual adalah informasi yang di dalamnya memiliki sebuah topik yang mendalam dan terpercaya. Informasi subjektif adalah informasi yang terdiri dari sebuah argumentasi seseorang dalam memberikan informasi tersebut. Sistem informasi objektif adalah informasi yang di ambil dari berbagai sudut pandang

\section{Arti Sistem Informasi}

Sistem informasi adalah sistem yang dimana bisa dapat diperoleh melalui online ataupun jaringan sosial. Menurut para ahli sistem informasi terdiri dari suatu pekerjaan, orang, dan teknologi informasi yang terorganisir. Jaringan internet memiliki peran yang cukup besar dalam mempengaruhi sistem informasi, sebagai penyediaan, penyimpanan, serta pemberian akses informasi kepada masyarakat luas. 
Di dalam sistem informasi juga memiliki beberapa komponen pendukung yaitu terdiri dari hardware, software, telekomunikasi, database dan data Warehouses, serta sumber daya manusia dan prosedur.

Hardware merupakan komponen pendukung pertama dalam mengakses sistem informasi, hardware dapat berupa komputer, televisi, serta smartphone untuk mudah mengakses informasi tersebut. Yang di mana hardware adalah yang paling pertama kita butuh kan dalam komponen pendukung untuk menjalankan suatu sistem.

\section{2}

Software merupakan salah satu komponen pendukung dalam sistem informasi, sebagai perangkat lunak dalam komputer, dan dibagi menjadi dua yaitu, sistem perangkat lunak dan sistem perangkat lunak aplikasi.

Telekomunikasi merupakan komponen pendukung untuk menghubungkan sistem portabel atau dengan perangkat lunak lainnya.

1 Database dan data Warehouses juga merupakan komponen pendukung sistem informasi, database ini merupakan data yang saling terhubung yang dapat memberikan informasi secara lengkap, contohnya seperti catatan karyawan atau catatan logistik.

Sumber daya manusia dan prosedur adalah komponen pendukung dalam sistem informasi yang paling penting di karena kan tanpa manusia sistem informasi dapat bergerak dan terakses serta sistem informasi tidak dapat berjalan dengan baik.

Pengertian sistem informasi dapat dikatakan sebagai seperangkat komponen teknologi. Komponen dari pengertian sistem informasi ini saling terhubung untuk mengumpulkan, menyimpan, memproses data, serta menyediakan informasi, pengetahuan, dan produk digital. Kinerja berdasarkan pengertian sistem informasi, kini digunakan oleh hampir semua sektor kegiatan dalam kehidupan masyarakat. Mulai dari kegiatan perusahaan bisnis untuk menghimpun data produk dan mengelola sumber daya. Melalui sistem informasi ini masyarakat dapat mengakses produk digital seperti e-book, pembuatan produk video, game online, serta dapat mengakses media sosial dengan mudah. Dan juga banyak para ahli pakar yang telah memberikan pandangan kepada sistem informasi.

Seperti yang dikatakan oleh Mcleod yang mengatakan pengertian suatu sistem informasi adalah "Sistem yang mempunyai 
kemampuan untuk mengumpulkan informasi dari semua sumber dan berbagai media untuk menyampaikan informasi”.

Dan menurut Tata Sutabri,Kom. MM.

"Sistem informasi adalah suatu sistem dalam organisasi yang membutuhkan pengolahan transaksi harian yang mendukung manajerial organisasi untuk menyerahkan kepada pihak-pihak tertentu dengan laporan- laporan yang diperlukan”.

Dan secara garis besarnya sistem informasi adalah suatu sistem yang dapat mengumpulkan informasi, menyimpannya, dan menyampaikan informasi untuk mencapai tujuan tertentu dan dapat diakses dengan lebih mudah.

Sistem informasi juga memiliki manfaat dan mempengaruhi dalam bidang-bidang tertentu antara lain bidang telekomunikasi, bidang bisnis, bidang kesehatan, bidang perbankan, dan sebagainya.

Bidang telekomunikasi salah satu bidang yang terkena pengaruh perkembangan sistem informasi diantara dalam komunikasi dari mulut ke mulut sekarang bisa menggunakan berbagai macam teknologi seperti smartphone dan sebagainya, serta dalam surat menyurat sekarang kita bisa menyampaikan informasi melalui SMS, whatsapp, dan lainnya.
Bidang bisnis juga merupakan yang paling terkena dampak dalam perkembangan sistem informasi antara lain dalam pengambilan keputusan, menganalisis, menyortir, serta dalam sistem perdagangan sekalipun. Dengan terkena dampaknya bidang tersebut maka yang dulunya kita berjualan dengan cara barter (tukar barang) sekarang kita telah mempunyai mata uang dan berbagai cara dalam memperjual belikannya seperti yang sekarang kita ketahui muncul banyaknya sistem yang telah di terapkan untuk membuat sebuah aplikasi yang mana sekarang kita dengan berada di rumah kita dapat menjual atau pun membeli sesuatu barang yang kita inginkan

Bidang kesehatan yang mana dengan adanya sistem informasi jika dulu pencatatan riwayat kesehatan pasien hanya ditulis sekarang bisa dengan di arsipkan di dalam komputer. Hal ini dapat memudahkan petugas dalam rekam medis pasien yang berbasis data pemeriksaan hasil laboratorium.

Bidang perbankan juga terkena dampak oleh sistem informasi yang di mana dulu menyimpan uang di dalam celengan dan tidak mengetahui berapa besar jumlah yang di tabung, namun sekarang dengan mengetahui jumlah nilai tabungan. Dapat juga menjamin keamanan penyimpanan uang kita di bank. 


\section{PEMBAHASAN}

\section{Makna Sistem Informasi Manajemen (SIM)}

Sistem informasi manajemen adalah integrasi yang terorganisir dari sistem perangkat lunak dan keras, data dan elemen manusia, dan seperangkat prosedur yang ketika di jalankan dapat memberikan informasi dalam mengambil keputusan. Sistem informasi manajemen merupakan disiplin mencakup penerapan orang, teknologi, dan prosedur kolektif untuk memecahkan masalah serta digunakan untuk mendukung fungsi operasi manajemen, analisis, serta pengambilan sebuah keputusan organisasi.

SIM menggunakan perangkat keras dan lunak komputer,dan perangkat ini dipadukan dengan manajemen untuk di analisis, perencanaan, pengendalian, pengambilan keputusan, dan database.

Tujuan dari sistem informasi manajemen adalah untuk membantu manajer dalam pengambilan keputusan yang cepat melalui penyajian informasi. Tujuan informasi manajemen adalah dibangun untuk menghasilkan atau memperoleh informasi manajemen yang akan di gunakan oleh para manajer dalam pengambilan keputusan.
Berikut tujuan sistem informasi manajemen: (a). Pengumpulan data (b). Pemrosesan data (c). Penyimpanan informasi (d). Pengumpulan informasi (e). Penyebaran informasi.

3 Sistem informasi manajemen akan memberikan manfaat bagi perusahaan. Berikut manfaat dari sistem informasi manajemen: (a). Fungsi perencanaan dan pengendalian (b). Mempermudah pelaporan (c). Mengendalikan biaya (d). Membantu membuat perbandingan (e). Menunjukkan kekuatan manajemen.

Adapun sistem informasi manajemen mempunyai ciri-ciri sebagai berikut: (a). Pendekatan sistem (b). Berorientasi manajemen (c). Berbasis kebutuhan (d). Berbasis pengecualian (e). Berorientasi masa depan (f). Terintegrasi (h). Perencanaan jangka panjang (i). Konsep sub-sistem (j). Dan berbasis data pusat. Dengan adanya sistem manajemen yang dapat membantu sebuah perusahaan atau seseorang dalam mengatasi permasalahan mereka maupun dari input dan output mereka.

\section{Sistem Pengambilan Keputusan (DSS)}

Pengertian sistem pengambilan keputusan (DSS) menurut Wainright Martin menyatakan bahwa "DSS is computer based 
system, almost always interactive, designed to assist a manager in making decision".

Sedangkan menurut Jogiyanto "DSS atau sistem pengambilan keputusan adalah suatu sistem informasi untuk membantu manajer level menengah untuk pengambilan keputusan setengah struktur supaya lebih efektif dalam menggunakan model analitis dan data yang tersedia".

Secara umum, DSS adalah sistem memberikan kemampuan baik dalam kemampuan pemecahan permasalahan maupun kemampuan mengkomunikasikan untuk masalah semi struktur, secara lebih khusus. DSS adalah sebuah sistem untuk mendukung kerja seorang manajer atau sekelompok manajer dalam memecah akar tidak struktur atau semi struktur dan dalam memberikan informasi atau usulan dalam menuju keputusan tersebut.

Dalam DSS digunakan suatu model sebagai dasar pengembangan alternatif yaitu berkaitan dengan permasalahan yang harus di selesaikan yaitu semi struktur atau bahkan tidak terstruktur, serta pemanfaatan komputer sebagai motor penggeraknya .

Menurut Turban, komponen sistem penunjang keputusan dapat di bangun dari sub-sistem berikut:

1) Sub sistem manajemen data. Meliputi basis data yang berisi data yang relevan dengan keadaan dan dikelola oleh software yang disebut

DBMS (Database management system).

2) Sub-sistem manajemen model berupa paket software yang berisi finansial, statistik, Manajemen, sains dan lain-lain yang menyediakan analisis yang sesuai

3) Sub sistem manajemen pengetahuan Merupakan sub-sistem yang mendukung sub-sistem lain atau berlaku sebagai komponen sendiri.

4) Sub-sistem antarmuka pemakai Merupakan sub-sistem yang dapat berkomunikasi dan memberikan perintah.

5) Pemakai Termasuk di dalamnya pemakai manajer dalam mengambil keputusan

Menurut Jogiyanto, komponen penting pengambilan keputusan terdiri atas tiga komponen yaitu, dialog manajemen, model manajemen, dan data manajemen.

Dialog manajemen adalah komponen input dan output, dan berdialog dengan menggunakan sistem.

Model manajemen adalah komponen yang dapat mengubah data menjadi informasi yang relevan.

Data manajemen adalah komponen data yang dapat diakses oleh siapa pun. 
Sistem pengambil keputusan mempunyai komponen lain yaitu, teknologi dan kontrol.

Komponen teknologi terdiri atas perang lunak dan perangkat keras. Perangkat lunak yang digunakan oleh DSS seperti database manajemen sistem, dan sebagainya

\section{Peranan Sistem Pengambilan Keputusan} (DSS) Dalam Sistem Manajemen

Sistem pengambil keputusan di gunakan oleh manajer hanya sebagai alat bantu bukan sebagai pengganti manajer sehingga keputusan tetap ada pada tangan manajer.

Sistem pengambil keputusan hanya dapat untuk mengumpulkan data, menganalisis, serta kegiatan yang di telah di lakukan sebelumnya. Dan dengan terkumpulnya manajer dapat lebih mudah untuk menyelesaikan masalah.

Menurut para pakar ahli yang terkemuka sistem pengambil keputusan mempunyai tiga tujuan manajer tercapai yaitu :

(1) Membantu manajer menyelesaikan masalah yang bersifat semi struktur.

(2) Mendukung manajer dalam mengerjakan masalah terstruktur dan manajer menyelesaikan masalah tidak struktur.

(3) Meningkatkan efisiensi dalam mengambil keputusan.
Ketiga tujuan ini bersangkutan dengan tiga prinsip dasar sistem pengambil keputusan yaitu, struktur masalah, dukungan keputusan, dan efektivitas keputusan.

Struktur masalah adalah dimana masalah yang struktur dapat di selesaikan dengan rumus yang sesuai, dan masalah yang tidak terstruktur tidak dapat di selesaikan dengan sistem pengambil keputusan (DSS) di karena kan (DSS) hanya dapat digunakan untuk majalah yang semi struktur.

Dukungan keputusan adalah di mana sistem pengambil keputusan tidak dapat mengambil segala keputusan dikarenakan hanya digunakan untuk sistem yang terstruktur sedangkan pengambil keputusan dari masalah yang tidak terstruktur hanya manajer yang akan menentukannya.

Efektivitas keputusan bukan untuk mempercepat pengambilan keputusan melainkan mengambil keputusan yang lebih baik, dan membantu manajer dalam mempercepat dalam mengambil suatu keputusan yang bersifat semi struktur.

Sama halnya sistem informasi manajemen, sistem pengambil keputusan (DSS), data dan database disimpan di dalam lingkup perusahaan isi database yang menggunakan tiga sub sistem perangkat lunak yaitu, perangkat lunak penulisan laporan, perangkat lunak model matematika, 
perangkat lunak GDSS (Group Decision Support System).

Perangkat lunak penulisan laporan adalah perangkat yang dapat menghasilkan laporan periodik atau pun laporan khusus. Contohnya melaporkan hasil pendapatan bulan lalu, dan riwayat absensi pegawai.

Perangkat lunak model matematika adalah perangkat lunak yang paling penting dalam (DSS) yang mana menghasilkan suatu informasi yang melibatkan beberapa komponen sistem fisik perusahaan. Keuntungan dalam menggunakan perangkat lunak model ini adalah meningkat kecepatan simulasi serta evaluasi keputusan dalam waktu singkat.

Perangkat lunak GDSS adalah perangkat lunak yang bekerja sama untuk memecahkan beberapa permasalahan dan mencapai sebuah solusi.

Perangkat sistem pengambil keputusan dapat melakukan penyerapan informasi berbasis data, konfigurasi data, kalkulasi, analisis data, optimasi, serta nonprobalistik yang dapat dilakukan melalui artifical intelligence. Penggunaan sistem pengambil keputusan (DSS) membantu manajer meningkatkan efisiensi dalam proses pengambilan keputusan, dan juga dapat menciptakan pengambilan keputusan bersifat strategis maupun taktik.
Perangkat DSS dimaksud untuk membantu manajer tingkat atas dan menengah dalam mengambil keputusan yang bukan dalam operasi rutin. DSS mampu melakukan penyerapan informasi berbasis data, konfigurasi data, kalkulasi, analisa stastik, optimasi, nonprobalistik (what if analysis) serta why analysis, yang dilakukan melalui program artifical intelligence. Oleh karena itu penggunaan DSS ini dengan tepat akan meningkatkan efektivitas manajer dalam pengambilan keputusan dan dapat meningkatkan efisiensi dalam proses pengambilan keputusan tersebut. Jadi DDS dapat menciptakan dimensi dukungan bagi pengambilan keputusan maupun bersifat strategis dan taktik.

Seorang manajer yang bereksperimen dengan berbagai model ${ }_{9}$ secara interaktif dengan data yang tepat, dapat menemukan dan mengevaluasi dengan cara yang lebih baik terhadap pilihan keputusan alternatif.

Dengan adanya sistem pengambilan keputusan dan dengan adanya data yang relevan manajer dapat mengambil keputusan dengan sangat baik tanpa harus menunggu waktu yang lama. Dan dengan sangat baiknya dalam pengambil keputusan manajer dapat melaporkan atau memberikan informasi dengar sangat relevan dan menguntungkan. 


\section{Kesimpulan}

Seiring berjalannya waktu teknologi berkembang pesat dan yang paling memberikan kontribusi paling besar dalam peradaban manusia dan di samping perkembangan teknologi manusia juga dapat memanfaatkan sistem-sistem untuk mempermudah dan menguntungkan dalam pemakainya.

Sistem-sistem ini juga mempengaruhi dalam berbagai bidang seperti bidang telekomunikasi, bisnis, kesehatan, perbankan, pendidikan, dan sebagainya

Dan dengan berkembangnya sistem informasi munculnya orang-orang yang memanfaatkannya untuk mendapatkan keuntungan dengan mendirikan perusahaan jasa seperti Go-jek, Grab, Sicepat, JNE, JNT, dan sebagainya

Dan dengan adanya sistem informasi yang mempengaruhi perdagangan elektronik yang lebih menguntungkan, lebih efisien, serta lebih mudah digunakan yang di sebut dengan e-commers.

Dan dengan adanya sistem pengambilan keputusan (DSS) yang mempermudah untuk para manajer tingkat menengah hingga atas untuk membantu menyelesaikan masalah mulai dari tidak struktur hingga semi struktur.
Dengan sistem pengambil keputusan (DSS) ${ }_{24}$ dapat mengambil keputusan yang lebih baik untuk mencapai suatu tujuan tertentu.

Seperti yang kita ketahui masih banyak selain kita yang tidak mengetahui atau terpelosoknya suatu daerah yang tidak mendapatkan dalam mengakses teknologi, oleh karena itu kita yang mengetahui dalam penggunaan teknologi kita harus membantu dan memajukan daerah mereka juga.

\section{Saran}

Berdasarkan yang saya uraikan di atas saran saya adalah untuk lebih mengembangkan diri sendiri dalam kemajuan teknologi.

Dapat memanfaatkan dan mengembangkan sistem informasi lebih efisien.

Melakukan sistem alternatif yang sekiranya lebih cepat dengan sistem DSS

Lebih mengembangkan metode dalam sistem DSS

Kita sebagai dapat membantu dalam kemajuan suatu daerah dengan memberikan bantuan kepada mereka yang daerahnya yang masih belum dapat merasakan tentang pentingnya teknologi untuk kehidupan.

\section{DAFTAR PUSTAKA}


Jogiyanto, H.M. (2001). Analisis \& Desain Sistem Informasi: Pendekatan Terstruktur Teori dan Praktek Aplikasi Bisnis. Edisi ke2. Penerbit Andi Offset Yogyakarta.

Jogiyanto, H.M. (2003). Sistem Teknologi Informasi: Pendekatan Terintegrasi Konsep Dasar, Teknologi, Aplikasi, Pengembangan dan Pengelolaan. Edisi ke-1. Penerbit Andi Offset Yogyakarta.

Sutedjo D., Budi (2003). Perencanaan \& Pembangunan Sistem Informasi. Penerbit Andi Offset Yogyakarta.

Turban; McLean; Wetherbe. 1999. Information Technology For Management. John Wiley \& Sons, Inc. USA.

Wainright, Martin E., Carol V. Brown, Daniel DeHayes, Jeffrey A. Hoffer, and William C. Perkins (2002). Managing Information Technology. Fourth Edition. Prentice-Hall, New Jersey.

Wijianto, Setyo Hari (2000). "Teknologi Informasi, Akuntansi dan Auditing: Suatu Kecenderungan". Konvensi Nasional Akuntansi IV.

Wilkinson, Joseph W., Michel J. Cerullo, Vasant Raval, and Bernard Wong-On-Wing (2000). Accounting Information System:
Essential Concepts and Applications. Fourth Edition. John Willey \& Sons Inc., New York

Anonimous 2005. MANAGERIAL DECISION MAKING AND DECISION SUPPORT SYSTEM. http://library.gunadarma.ac.id/files/disk1/5/ jbptgunadarma-gdl-course-2005timpengaja-202-dss.doc.

Sudjatmiko 2008 DSS (Materi Kuliah) MTIUGM. Yogyakarta. http://id.wikipedia.org/wiki/Sistem_pendu kung_keputusan

Sheldon Shen (1987). Knowledge Management in Decision Support Systems. Ohio State University Of Columbus, USA. Saliman Saliman 2010. Mengenal Decision Support System (DSS). Dikutip dari: https://journal.uny.ac.id/index.php/efisiensi /article/view/3971

Ananda Liana Putri (2014). Tugas Mata Kuliah Sistem Informasi Manajemen. Dikutip dari: https://www.academia.edu/42686269/Tuga s_Mata_Kuliah_Sistem_Informasi_Manaje men Judul Peranan Sistem Pendukung Keputusan_DSS_Decision_Support_Syste m 
Muhammad_Abrar_Zaihary_PIK.docx

ORIGINALITY REPORT

$25 \%$

SIMILARITY INDEX
$25 \%$

INTERNET SOURCES
$5 \%$

PUBLICATIONS
$1 \%$

STUDENT PAPERS

PRIMARY SOURCES

1 id.berita.yahoo.com

Internet Source

2 pt.scribd.com

Internet Source

3 hot.liputan6.com

Internet Source

4 aldino-b-p-fisip11.web.unair.ac.id Internet Source

5 text-id.123dok.com

Internet Source

6 es.scribd.com

7 www.merdeka.com

Internet Source

Muhammad Nurtanzis Sutoyo. "Implementasi

Metode MADM Model Yager untuk Seleksi

Penerima Beasiswa PPA", JUITA : Jurnal

Informatika, 2018

Publication 
10 aldinosepta.wordpress.com

11 docplayer.info

12 doku.pub

13 jurnal.pancabudi.ac.id

14 pengajar.co.id

15 www.gurudaridesa.com

16 123dok.com

17 journal.umg.ac.id

18 amenakao.blogspot.com

19 belajar-ilmiah.blogspot.com 
21 gmanagement2016.blogspot.com

22 m.liputan6.com

24 muttaqimah.wordpress.com

25 repository.iainpurwokerto.ac.id Internet Source 